\title{
Study on a New Isolate of Rabbit Haemorrhagic Disease Virus
}

\author{
A. Y. Metwally ${ }^{1}$, H. M Madbouly ${ }^{2}$. \\ ${ }^{1}$ Animal Health Research Institute Kafr El-Sheikh Provincial laboratory \\ ${ }^{2}$ Virology Deptartment Faculty of Veterinary Medicine Beni-Suef University, Egypt
}

\begin{abstract}
Fifteen outbreaks with clinical picture and post- mortem lesions similar to that of rabbit haemorrhagic viral disease (RHVD) were investigated in vaccinated flocks during the period between February and July 2005 at Kafr El-Sheikh Governorate. Twelve representative liver homogenate were positive in haemagglutination test (HA) using human type $(O)$ washed RBCs, with titer more than $1 / 160$. Detection of virus particles by electron microscopy, histopathological findings as well as pathogenicity test , confirmed that the outbreaks were RHVD. The possible role of field rats for the transmission and spread of RHVD among rabbitaries was studied. Cross reactivity and cross protection tests were conducted. These tests proved that the newly emerged RHVD isolates were not closely related to classical local vaccinal strain of RHVD and may be a variant strain.
\end{abstract}

Rabbit haemorrhagic viral disease (RHVD) is an acute, febrile, fatal, highly contagious viral disease affecting rabbits; the disease caused by a virus belongs to family Caliciviridae. The disease is characterized by sudden deaths, fever, dyspnea and abdominal respiration, as well as frothy bloody nasal discharges (O I E, 2000). RHVD was first reported in China in 1984 by Liu et al., then outbreaks have been reported in many countries including Korea (Lee and Park 1987), Italy (Cancellotti et al., 1988), France (Morisse, 1988), Mexico (Gregg et al., 1989), Bulgaria (Belemzov et al., 1989), Germany (Soike et al., 1989), Spain (Rosell and Badiola 1989), Belgium (Peeters et al., 1990) and England (Chasey and Duff 1990). In Egypt RHVD has been diagnosed for first time by (Ghanem and Ismail 1992, Salem and and ElBallal 1992) since that time, RHVD outbreaks were reported in several regions of Egypt (ElZanaty 1994, Azhar et al., 1995, El-Mongy 1998 and Mostafa, 2001).

An inactivated formalized tissue vaccines prepared from liver suspensions of rabbits infected with RHVD have been developed in several countries including Egypt (Gunenkov, 1990; Abd El-Motalib et al., 1998 and Daoud et al., 1998). However outbreaks having the same clinical picture and post mortem lesions as those of RHVD was observed in rabbit flocks that vaccinated with formalized RHVD vaccine prepared from local vaccinal strain by Serum Vaccine Research Institute SVRI at a period from February till July
2005.

The present work was planned to identify and characterize the proposed new RHVD isolate and detect its antigenic relationship to the locally existing vaccinal strain. The suspected role of field rats (Rattus rattus norvigcus) in spread and transmission of such isolate was also investigated.

\section{Material and Methods}

Specimens. Fifteen farm rabbits exhibiting symptoms and lesions suspected to be RHVD at Kafr El-Sheikh Governorate were investigated during the period from February until July 2005. Clinical and post mortem examination were conducted and recorded.

Serum samples. Thirty six pooled sera were collected from survived rabbits after 3-4 weeks from the beginning of the outbreak for assessing haemagglutin inhibiting antibodies by haemagglutination inhibition test (HI). The test was applied according to (OIE 1996).

Sample preparation. About 2-3 livers per farm were pooled and used for virus detection. These livers were cut by a sterile scissors into small pieces and ground in a sterile mortar, homogenized and suspended with saline to reach $20 \%(\mathrm{w} / \mathrm{v})$ suspension. Samples were frozen and thawed for 3 cycles and then centrifuged by lowspeed centrifugation at $3000 \mathrm{rpm}$ for $15 \mathrm{~min}$. Supernatant fluid was collected and was stored at $-20{ }^{0} \mathrm{C}$ and used for virus detection by haemagglutination test and electron microscopy.

Haemagglutination test (HA). HA test was 
carried according to OIE (1996) using $1 \%$ human type (O) washed RBCs. Agglutination at end point dilution more than $1 / 160$ was considered positive.

Detection of haemagglutinating activity and elution pattern. The ability of liver homogenate to agglutinate human type $(\mathrm{O})$, chicken and sheep washed RBCs (1\%) was screened. Equal volumes of liver homogenates $(100 \mu \mathrm{l})$ and of $1 \%$ washed RBCs were thoroughly mixed and observed for haemagglutination activity. The positive plates of human type $(\mathrm{O})$ washed RBCs were covered and incubated for $24 \mathrm{~h}$ at $4{ }^{\circ} \mathrm{C}$ to record elution pattern (according to OIE, 1996).

Transmission electron microscopy examination. Supernatant fluid of liver homogenate (HA titer $1 / 320$ ) was ultra-centrifuged through sucrose cushion at $30.000 \mathrm{rpm}$ for $1 \mathrm{~h}$. by high-speed centrifuge. The sediment was stained with Uranyl acetate, after loading on copper grid. Electron micrograph examination was made using TEM ZEISS EM 10 (Germany) at HT $60 \mathrm{KV}$.

Histopathological examination. Tissue specimens were collected from liver, lung, spleen and kidney of naturally infected rabbit. Tissue samples were fixed in $10 \%$ neutral buffered formalin, processed for paraffin embedding techniques, sectioned at 4-6 microns thickness, strained with haematoxyline and eosin (H\&E) and microscopically examined (Bancroft et al., 1996).

Pathogenicity test in rabbits. Five New-Zealand rabbits of age over three months were infected intra-nasally with a dose of $1 \mathrm{ml}$ liver homogenate (HA titer was 1/320). Two rabbits were separately kept as control non-infected. All rabbits were daily observed for clinical signs and mortality for 15 days.

Hyperimmune serums. Hyper immune sera from local vaccinal strain (SVRI) and the new isolate of RHVD (KSHM05) were prepared in New-Zealand rabbits, by three inoculations (one week interval) with addition Fruend's adjuvant, then blood was collected one week post last vaccination. The prepared sera were used for HI test.

Cross haemagglutination inhibition test. Hyper immune serum prepared from local vaccinal strain (SVRI) and from new isolate RHVD were inactivated at $56{ }^{\circ} \mathrm{C}$ for $30 \mathrm{~min}$. in water bath, then $(50 \mathrm{ul}$ of each inactivated serum was thoroughly mixed with an equal volume of liver homogenate (HA activity more than 1/160). The serum-virus mixtures were incubated at room temperature for 1 h. then $1 \%$ human type $(\mathrm{O})$ RBCs was added to wells of the plates and haemagglutination activity was observed for each virus serum mixture.

Cross protection test. Thirty 3-month-old white New-Zealand rabbits were equally divided into three groups (A, B and C) and kept in separate units. Group A was vaccinated with local vaccinal stain (SVRI) with $0.5 \mathrm{ml}$ sub-cutuneously $(\mathrm{s} / \mathrm{c})$, group B was inoculated with prepared vaccine from field new isolate (KSHM05) $0.5 \mathrm{ml} \mathrm{s} / \mathrm{c}$, while group $\mathrm{C}$ was left as unvaccinated control. All groups were challenged at one week post vaccination intranasally with $1 \mathrm{ml}$ of RHVD positive liver homogenate (HA titer was $1 / 320$ ). All rabbits were daily observed for clinical sings and/or mortality for 15 days.

Pathogenicity test in field rat (Rattus rattus norvigics). Ten adult field rats were infected intranasally with rabbit liver homogenate (HA titer $1 / 320$ ) with $0.5 \mathrm{ml} /$ rat. Rats were observed for 15 days to record any clinical symptoms or mortality. Livers from affected rats were harvested to estimate haemagglutination activity. Group of five field rats kept as control non-infected.

\section{Results}

Clinical and post-mortem examination. The clinical signs observed on susceptible rabbits (more than two months old) were sudden deaths, depression, convulsion, fever with cyanosis of lips and nostrils, dyspnea accompanied by abdominal respiration and cries. Frothy bloody nasal discharge was occasionally observed (Fig. 1). Sometimes, anal sphincter appeared loosen with mucoid faecal discharges.

The most prominent lesions were confined to the liver, whereits colour was pale yellowishbrown with focal and lobular necrosis. Haemorrhage of variable size appeared scattered through the liver (Fig. 2). Lungs were congested, oedematous and haemorrhagic (Fig. 3). Digestive lesions involved full-filled stomach engorged blood vessels, with apparently characteristic necrotic spots visible from external and internal gastric surfaces (Fig. 4). Dark congested spleen. Dark red kidneys with urinary bladder filled with discolored urine (Fig. 5).

Haemagglutination inhibition test (HI). HI of serum samples collected from rabbit farms under investigation revealed HI titer ranged from 2-7 $\log _{2}$. 
Table (1): HA activity and elution pattern liver homogenates of infected rabbits suspected to be RHDV.

\begin{tabular}{cccccc}
\hline Status & R.B.Cs. & Tested & Positive & \% Positive & HA titer \\
\hline \multirow{3}{*}{ HA activity } & Human type (O) & 15 & 12 & $80 \%$ & $160-640$ \\
& Chicken & 15 & 12 & $80 \%$ & $160-640$ \\
Elution & Sheep & 15 & 10 & $65 \%$ & $160-640$ \\
\hline
\end{tabular}

Table (2) HI antibody titers of sera of survived rabbits.

\begin{tabular}{lccccccccccc}
\hline & \multicolumn{10}{c}{ HI antibody titers } \\
\cline { 2 - 12 } Log 2 titer & 1 & 2 & 3 & 4 & 5 & 6 & 7 & 8 & 9 & 10 & 11 \\
\hline Positive tested sera & - & 4 & 3 & 2 & 6 & 8 & 13 & - & - & - & - \\
Total No & & & & & & 36 & & & & & \\
\hline
\end{tabular}

Table (3): Cross HI test.

\begin{tabular}{ccc}
\hline Type of tested sera & RHDV & HA reactivity \\
\hline Serum of vaccinal strain & KSHM05 & positive \\
Serum of KSHM05 & KSHM05 & negative \\
\hline
\end{tabular}

Haemagglutination test (HA). The ability of 20 $\%$ liver homogenates (from 15 RHVD suspected cases) to haemagglutinate human type (O) RBCs revealed that 12 samples were positive with a titers ranged from $1 / 160$ to $1 / 640$.

Haemagglutination activity and elution pattern against human type (O), chicken and sheep RBCs. RHD virus has the ability to rapidly haemaagglutinate human type $(\mathrm{O})$, chicken and sheep RBCs at room temperature. Twelve out of 15 liver homogenates from RHVD suspected cases to haemagglutinate human type (O) RBCs revealed that 12 samples were positive with a titers ranged from $1 / 160$ up to $1 / 640$ (Table 1).

HA elution pattern of 12 RHD virus samples against human type (O). All tested samples retained the same HA titers, so RHD viruses are not eluted from human type ORBCs.

Result of electron microscopy. Non-enveloped, spherical virion, 35-40 nm diameter with surface projection were observed (Fig. 6).

Histopathological findings.

Pathogenicity test in rabbits. The infected rabbits exhibiting the same clinical picture and post mortem lesions that described in naturally infected rabbit with mortality reached $100 \%$ within 3-5days post-experimental infection. In addition, liver homogenate prepared from dead animal has haemagglutination activity against human type (O) RBCs. On the other hand, the non-infected rabbits appeared healthy. Cross haemagglutination inhibition test. Haemagglutination of newly isolated RHD virus was not inhibited by serum prepared from local vaccinal strain (SVRI) On the other hand Haemagglutination was inhibited by using serum prepared from new isolate RHD virus (Table 5). Cross-protection test. Rabbits in group A, that were vaccinated with local vaccinal strain (SVRI) and challenged with new isolate RHD virus, exhibited depression, convulsion, fever and dyspnea $48 \mathrm{~h}$. post-infection, death recorded $12 \mathrm{~h}$ after appearance of signs. Seven out of 10 infected rabbits $(70 \%)$ were died, rabbits in group $\mathrm{B}$, that were vaccinated with vaccine prepared from local isolate exhibited mild respiratory, but no mortality was recorded. Moreover group C, non-vaccinated challenged group, the infected rabbits exhibited 
Table (4) Results of cross protection test.

\begin{tabular}{|llcll|}
\hline Group & Vaccine & Morbidity & Mortality & HA activity* \\
\hline A & VSRI & $10 / 10$ & $7 / 10$ & positive \\
B & KSHM05 & $0 / 10$ & $0 / 10$ & negative \\
C & no & $10 / 10$ & $10 / 10$ & positive \\
\hline
\end{tabular}

*HA test was done on liver homogenates of challenged rabbits
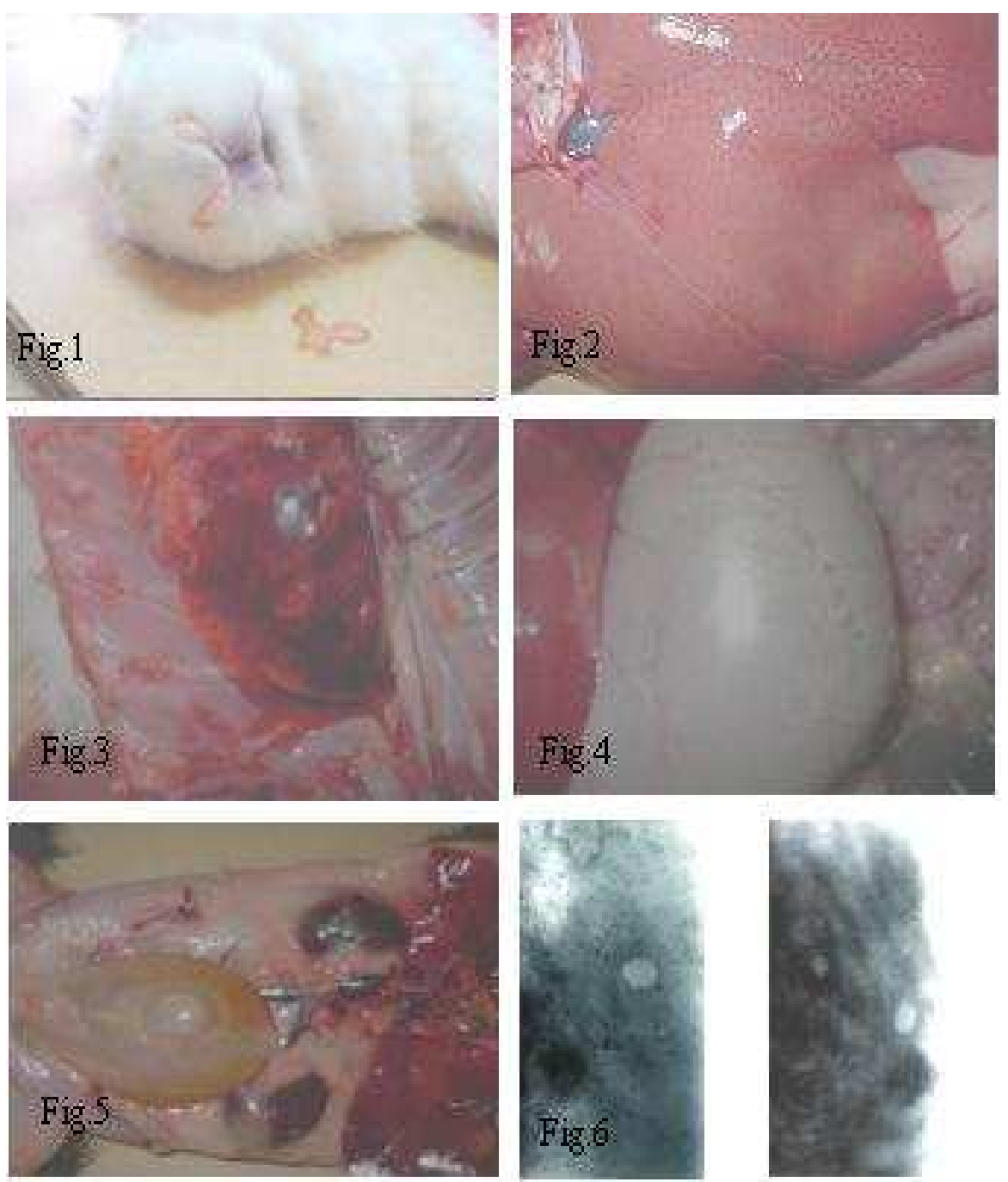

Fig. (1): Rabbit showing cyanosis of lips and nostrils with frothy bloody nasal discharge. Fig. (2): Rabbit liver showing focal and lobular necrosis with hemorrhagic area.

Fig. (3): Rabbit lung showing congestion and hemorrhagic area.

Fig. (4): Rabbit stomach showing engorged peripheral blood vessels with necrotic spots.

Fig.(5): Rabbit kidney showing sever congestion with urinary bladder impacted with discolored urine.

Fig. (6): Electron micrograph of negative stained Calici virus (x 30000). 
depression, dyspnea, mucoid faeces, as well as frothy bloody nasal discharges observed in some cases. Mortality was $100 \%$. Liver homogenate prepared from dead rabbits haemagglutinates human type (O) RBCs (Table 4).

Pathogenicity test in field rats. Rats inoculated with RHVD new isolate exhibited depression, convulsion, dyspnea and abdominal respiration rate was $70 \%$. Post mortem examination of dead rats showed general congestion. Mortality four out of seven Liver homogenate prepared from dead rats, haemagglutinated human type (O) RBCs. Non-infected control rats exhibited, some depression.

\section{Discussion}

RHVD is one of the major viral disease affects and threatens rabbit populations. It was first described in the People's Republic of China in 1984 (Liu et al., 1984), Europe between 1987 and 1989 (Morisse et al., 1991) and in Egypt during winter and spring of 1992 (Ghanem and Ismail, 1992).

RHVD is responsible for high economic losses in rabbitries due to the high mortality rates in adults or young animals older than two months.

In the present study, 15 outbreaks in rabbit farms with clinical picture similar to RHDV during the period of February to July 2005 were investigated. All rabbits flocks were vaccinated with local vaccinal strain (SVRI) through January, February or March, the outbreak firstly observed in advanced pregnant rabbit does or within one week post partum with mortality around $30 \%$. The disease than spread among young rabbits (2-3 months age), with $50 \%$ mortality. This field observation lead us to speculate that more than one antigenically dissimilar RHD virus strains may exist.

In the present study, the clinical signs and lesions of naturally and experimentally infected rabbits, detection of viral agents by electron microscopy and haemagglutination activity of infected liver homogenate confirm that the disease described above has many similarities with description of RHVD. However, the outbreaks recorded in vaccinated flocks at susceptible age.

Cross haemagglutination inhibition assay and cross protection tests suggested that the proposed new isolates of RHD virus cannot be ruled out and not closely related to RHD classical vaccinal strain and there is little immunological relationship between isolated strain and the currently used vaccine. Higher mortality rates in cross protection test might be attributed to antigenic variation or deviation. These results are generally in agreement with that recorded by (Capucci et al., 1996) who characterized a variant strain of RHDV "Rain ham" originally isolated from England; the strain appeared to be antigenically indistinguishable from other known isolates. Moreover, (Le Gall et al., 2003) undertaken molecular epidemiological study of RHD virus in France between 1988 and 1995 and demonstrated that the multiple sequence alignments of the $\mathrm{VP}_{60}$ gene and antigenic analysis with monoclonal antibodies proved that these French isolates are two new isolates of the RHD virus variant. Furthermore, (Marchandeau et al., 2005) suggested the existence of non-protective antibodies due to putative RHD like virus during RHVD outbreak in France 2001, this viral strain was not putative variant and not neutralized by antibodies.

Pathogenicity test in field rats proved that field rats susceptible to infection with new isolates RHD virus might play a role in disease transmission to rabbits. Similar results reported by (Borja and Larios 1990) who mentioned that rats could act as important mechanical vectors of RHD virus. Xu, (1991) reported that rodents are mechanical means of transmission and cannot be ruled out.

These results indicated that the field rats play an epidemiological role for transmission of RHD virus among rabbit flocks and may act as potential carries so, field rats must be considered in programs and policies applied for the control of RHVD.

It could be concluded that the results of cross haemagglutination inhibition assay and cross protection test may confirm the possibility of antigenic variation of new isolate RHVD in recent outbreaks. Meanwhile, more investigations are required to examine these newly isolates using monoclonal antibodies, or molecular approaches to determine the possible antigenic variation and formulate effective and protective vaccines from field isolates.

\section{References}

Abd El-Motlib, T. Y.; Abd El-Gawad, A. M. and Azzaz, H. H. (1998): Viral haemorrhagic disease of rabbit: Comparative 
study between the immune response of local and imported vaccine. Assiut Vet. Med. J., 40 (79): 150-156.

Azhar, M. A.; Ashgan, M. S.; Soliman, A. M. and Bayoumi, A. H. (1995): Rabbit viral haemorrhagic disease Beni-Suef, Vet. Med. J., 5 (1): 17-22

Bancroft, J. D.; Steven, A. and Turner, D. R. (1996): Theory and practice of histological techniques, $4^{\text {th }}$ ed. Churchill living stone Edinburgh, London, Melbourne and New York.

Belemezov, P.; Petkov, A.; Mitov, P. and Peshev, R. (1989): Pathological features of viral haemorrhagic disease of rabbits. Veteinarna Sbirka, 87 (10): 17-21.

Broja, G. and Larias, O. M. D. (1990): Determination de la viabilidad del virus de la EHV cen alfalfa, alimento balanceado commercial costales paraalimentoy ratas. Fac. Vet. Med., Unam, Mexico (Thesis).

Cancellohi, F. M.; Villeri, M. and Manfreini, R. (1988): Occurrence of $\mathrm{x}$-disease of rabbits. Rivista di coinglicoltura, 25 (9): 41-46.

Capucci, L.; Chasey, D.; Lavazza, A. and Westcott D. (1996): Preliminary characterization of non haemagglutinating strain of rabbit hemorrhagic disease virus from United kingdom. J. Vet. Med., Series B, 43 (4): 245250.

Chasey, D. and Duff, P. (1990): Rabbit hemorrhagic virus disease Vet. Rec., 126: 623.

Daoud, A. M.; Khodeir, M. H.; Abbass, A. M. and Ibrahim, S. I. (1998): Preparation of a specific inactivated vaccine against RHVD $4^{\text {th }}$ Sci. Cong., Fac. Vet. Med. Zag. Univ. Egypt, pp. 230-234.

El-Mongy, F. A. (1998): Studies on viral hemorrhagic disease of rabbits Ph.D. Thesis, Fac. Vet. Med. Moshtohor. Zag. Univ. Banha, Egypt.

El-Zanaty, K. (1994): Some investigations on rabbit viral hemorrhagic disease in upper Egypt. Assiut Vet. Med. J., 30 (60): 293-305

Ghanem, I. A. and Ismail, A. N. (1992): Occurrence of rabbit hemorrhagic disease in Sharkiaa province. Zag. Vet. Med. J., 20 (4): 491-502.

Gregg, D. A.; Wilson, C. and House, C. (1989): Necrotic hepatitis of rabbits in Mexico. A parvo virus. Foreign Anim. Dis. Rep., 17 (2): 7-10.

Gunenkov, V. V. (1990): Viral hemorrhagic disease of rabbits. Veterinariya (Moskova), 5: 13-15.

Le Gall, G. R.; Zwingelstien, F.; Laurent, S.; Boisseson,
C.; Portejoie, Y. and Rasschaert, D. (2003): Phylogenetic analysis of rabbit hemorrhagic disease virus in France between 1993 and 2000 and the characterization of RHDV antigenic variants. Arch. Virol., 148(1): 65-81.

Lee, C. S. and Park, C. K. (1987): Aetiological studies on an acute fatal disease of Angora rabbits. Korean J. Vet. Res., 27 (2): $277-290$.

Liu, S. J., Xue, P.; Pu, B. and Qion, N. H. (1984): A new viral disease in rabbits. Anim. Husb. Vet. Med., 16 (6): 253 255

Marchandeau, S.; Le Gall, G. R.; Bertagnoli, S.; Aubineau; J., Botti; G. and lavazza, A. (2005): Serological evidence for a non-protective RHDV-like virus. Vet. Res., 36 (1): 53-62.

Morisse, J. P. (1988): The hemorrhagic septicemia syndrome in the rabbits first observation in France. Le point Veterinaire, 20 (117): 835- 839.

Morisse, J. P.; Le Gall, G. and Boilletol, E. (1991): Hepatitis of viral origin in leporidae. Introduction and etiological hypotheses Rev. Sci. Tech. off. Int. Epiz., 10: 283295.

Mostafa, A. A. (2001): Characterization and pathogenicity of locally isolated virus of hemorrhagic disease in rabbit. Ph.D. Thesis, Fac. Vet. Med. Beni-Suef, Cairo Univ., Egypt.

OIE (1996): Viral hemorrhagic disease of rabbits. Manual of standards for diagnostic tests and vaccines, pp. 590-592.

OIE (2000): Viral hemorrhagic disease of rabbits. Maual of standards for diagnostic tests and vaccines, pp. 1-14.

Peeters, J. E.; Charlier, G. and Broes, A. (1990): First observation of rabbit hemorrhagic disease in Belgium. Annales de Med. Veterinaire, 134 (8): 567-571.

Rosell, J. M. and Badiola, J. J. (1989): Viral haemorrhagic disease of rabbits Epidemiology and control. Cuniculture (Paris), 89: 21-26.

Salem, B. and El-Ballal, S. S. (1992): The occurrence of rabbit viral hemorrhagic disease (RHVD) in Egypt. Assiut Vet. Med. J., 27 (53): 295-304.

Soike, D.; Wilke, L.; Tutte, B.; Stropp, M., Rosler, D.; Rummler, H. J.; Richter, W.; Werdier, H.; Schluter, H. and Bohmer, R. (1989): Initial results of diagnosis and control of hemorrhagic septicemia of rabbits in the Potsdam region of Germany. Mh. Vet. Med., 44: 376-378.

Xu, W. Y. (1991): VHD of rabbits in the People's Republic of China. Epidemiology and virus characterization. Rev. Sc. Tech. OIE (Paris), 10 (2): 393-408. 